\title{
EFEKTIVITAS STRATEGI PEMBELAJARAN DAN PENGALAMAN GERAK TERHADAP KREATIVITAS GERAK SISWA KELAS AWAL SEKOLAH DASAR
}

\section{MOHAMAD SYARIF SUMANTRI ${ }^{1}$-ENENG YUNENGSIH ${ }^{2}$-HASANUDIN ${ }^{3}$}

\author{
PGSD FIP Universitas Negeri Jakarta \\ J1 Rawamangun Muka Jakarta, 13220, JakartaTimur \\ E-mail: mohamadsumantri@gmail.com
}

\begin{abstract}
The objective of the research is to study the effect of learning strategy and movement experiences toward the movement creativity of early primary student. The research used $2 X 2$ factorial design and was with $n$ of 48 children who was selected by simple random sampling technique. The results of the research are: (1) there is a significant difference of the movement creativity between those who are given taught by Inductive learning strategy and deductive learning strategy in the process of movement creativity. The movement creativity of those who are given taught by inductive learning strategy is higher than those who are given taught by deductive learning strategy. (2) for student who have high a experiences movement, it was found that student movement creativity taught by inductive learning strategy is higher than deductive learning strategy. (3) for the student who have low experirnces movement, it was found that the children movement creativity taught by deductive learning strategy is not different than inductive learning strategy. (4) there is an influence of interaction between giving the learning strategy and experiences movement towards the early primary movement creativity. It can be concluded that learning strategy and experiences movement in the student creativity.
\end{abstract}

Keywords: Learning strategy, experiences movement, movement creativity

\begin{abstract}
Abstrak: Tujuan dari penelitian ini adalah untuk mempelajari pengaruh strategi pembelajaran dan gerakan pengalaman terhadap kreativitas gerakan mahasiswa primer awal. Penelitian ini menggunakan 2 X 2 desain faktorial dan dengan n 48 anak yang terpilih dengan teknik simple random sampling. Hasil dari penelitian ini adalah: (1) ada perbedaan yang signifikan dari kreativitas gerakan antara mereka yang mengingat diajarkan oleh strategi pembelajaran induktif dan strategi pembelajaran deduktif dalam proses kreativitas gerakan. Gerakan kreativitas mereka yang mengingat diajarkan oleh strategi pembelajaran induktif lebih tinggi daripada mereka yang mengingat diajarkan oleh strategi pembelajaran deduktif. (2) bagi siswa yang memiliki tinggi gerakan pengalaman, ditemukan bahwa gerakan mahasiswa kreativitas diajarkan oleh strategi pembelajaran induktif lebih tinggi dari strategi pembelajaran deduktif. (3) untuk siswa yang memiliki gerakan experirnces rendah, ditemukan bahwa kreativitas gerakan anak-anak diajarkan oleh strategi pembelajaran deduktif tidak berbeda dari strategi pembelajaran induktif. (4) ada pengaruh interaksi antara pemberian strategi pembelajaran dan pengalaman gerakan ke arah kreativitas gerakan utama awal. Dapat disimpulkan bahwa strategi pembelajaran dan pengalaman gerakan dalam kreativitas siswa.
\end{abstract}

Kata kunci: Strategi Belajar, pengalaman gerakan, kreativitas gerakan 


\begin{abstract}
Setiap pendidik tentu menginginkan siswanya dapat tumbuh dan berkembang menjadi siswa yang kreatif, karena siswa yang kreatif biasanya cenderung lebih dapat memecahkan aneka masalah yang harus dihadapinya, terlebih lagi jika kelak siswa telah dewasa.
\end{abstract}

Sekolah Dasar merupakan lembaga yang paling mendasar menempati posisi yang sangat strategis dalam pembangunan sumber daya manusia. Siswa kelas awal SD merupakan usia dalam masa keemasan bagi perkembangan fisik dan mental siswa tersebut.

\section{Kreativitas Gerakan}

Hasil penelitian Erken (2011: 594) menunjukan potensi kreativitas penting untuk dikembang sejak awal SD terutama dalam mengembangkan kemampuan berfikir kritis, rasa percaya diri melalui aktivitas konrit beragam dan pendekatan terbuka seperti bermain dan melibatkan seluruh panca indra siswa. Hal senada juga dikemukkkan oleh Taylor (1988: 99) potensi kreativitas penting untuk dikembang sejak awal
SD adalah mengembangkan kemampuan berfikir kritis, rasa percaya diri melalui aktivitas konrit beragam dan pendekatan terbuka seperti bermain dan melibatkan seluruh panca indra siswa.

Berdasarkan hasil survey oleh Jautakyté (2014: 84)terhadap 174 guru pendidikan Anak usia dini menunjukan pentingnya pendidik mengorganisasikan aktivitas kreatif pada siswa sekolah melalui lingkungan dan kegiatan dan alat yang bervariasi dan sebagai besar guu meyakini krativitas sangat berhubungan dengan tingkat rasa percaya diri siswa.

Brusic (2014: 11-15) mengemukakan bahwa merangsang dan memupuk kreativitas siswa adalah salah satu upaya yang perlu dilakukan guru untuk mendapatkan siswa yang kreatif. Pendidikan yang diberikan melalui rangsangan yang positif dapat mengembangkan kemampuan dan menumbuhkan kreativitas siswa. Sejak dini siswa memerlukan rangsangan-rangsangan yang dapat mengasah potensinya.

Cheung (2010: 377-385) menyatakan bahwa faktor eksternal 
dan internal dapat mempengaruhi kreativitas seseorang. Faktor eksternal yang dapat memupuk perkembangan kreativitas seseorang adalah lingkungan yang memberikan keamanan psikologis dan kebebasan psikologis.

Sekolah sebagai lingkungan kedua setelah keluarga juga berpengaruh terhadap kreativitas siswa. Sejalan dengan itu perlu dikembangkan iklim pembelajaran yang dapat menumbuhkan rasa percaya diri serta sikap prilaku yang inovatif dan kreatif. Bergstein (2010: 30) menegaskan bahwa kreativitas gerak adalah “......Creative movement is an art form whose medium is the human body in motion. The four basic elements of dance are the body and its different parts and range of movement, and space, time, and energy".

Bergstein di atas menjelaskan bahwa kreatif gerak adalah sebuah bentuk seni menengah dari tubuh manusia dalam gerakan. Empat elemen dasar tari dalam tubuh dan bagian yang berbeda dan berbagai gerakan, dan ruang, waktu, dan energi

\section{Strategi Pembelajaran}

Para ahli pendidikan menemukan bahwa cara belajar yang paling tepat diterapkan pada siswa kelas awal SD adalah melalui kegitan induktif seperti bermain. Melalui kegiatan induktif, siswa memperoleh kesempatan untuk bereksplorasi dan bereksperimen dengan bebas sesuai dengan kreativitas dan imajinasi mereka. Kegiatan induktif dapat membantu siswa dalam memahami konsep sesuai dengan karakteristik perkembangannya.

Kegiatan induktif yang dimaksud adalah pendekatan terbuka atau konvergensi seperti halnya kegiatan bermain, kegiatan yang menuntut bergerak bebbas, bereksplorasi, guru banyak menakankan pada jumlah waktu bergerak siswa yang optimal (Student engage og time in activity) dengan demikian siswa mampu mengembangkan potensi yang tersembunyi di dalam dirinya, secara aman, nyaman, dan menyenangkan.

Temuan penelitian oleh Lehrer (2012: 295) paada siswa kelas awal usia 6 dan 7 tahun berjumlah 56 anak dengan kegiatan diluar kelas 
menyimpulkan bahwa pendekatan induktif berbasis permainan jasmani, bermain konstruktif, berhubungan dengan kreativitas anak siswa kelas awal.

Pada kenyataannya masih ada sebagian orang yang berpikir bahwa bermain hanya penting untuk mengisi waktu luang siswa. Selain itu, masih lembaga pendidikan SD yang belum dapat menyediakan lingkungan belajar yang dapat merangsang kreativitas siswa.

Namun masih banyak guru kelas SD dalam membelajarkan gerak sebagai besar menggunakan cara konvensional yaitu dengan metode komando, imitatif, duplikasi, foto copi yaitu guru mencoba memberi contoh gerak dan siswa harus meniru gerakan persis yang dilakukan guru, siswa pasif tidak melibatkan aspek kognitif, belajar gerak hanya mentransfer model gerak saja, atau siswa dituntut menduplikasi gerak yang dicontohkan guru, cara mengajar demikian dapat mematikan kreativitas gerak siswa karena guru menjadi pusat pembelajaran, siswa harus mengikuti bentuk gerak yang sudah ditentukan oleh guru.

Menurut Priadharma (2001) ada empat unsur kreativitas yaitu percaya diri, integritas, kasih sayang, dan intuisi. Kreativitas mempunyai kaitan erat dengan yang disebut percaya diri, karena tanpa adanya percaya diri seseorang tidak dapat berpikir kreatif, mereka terjebak pada kekwatiran dan ketakutan untuk berpikir dan berbuat lain.

Pengembangan kreativitas banyak didominasi oleh kegiatan di dalam kelas dan aktivitas jasmani lebih banyak fokus pafada pengembangan jasmani saja padalah sangat mungkin disana dapat mengembangkan kreativitas, kerativitas melalui gerak belum banyak diteliti. Berkaiatan hal tersebut maka pening untik mengetahui peran pendeatan yang dapat mensdimulas keativitas. Penelitian dilakukan oleh Ramdhani (2012) menghasilkan kesimpulan penggunaan model pembelajaran induktif-deduktif dapat meningkatkan hasil belajar pada pembelajaran teknik dasar servis bawah bolavoli siswa kelas $\mathrm{X}$. 
Berdasarkan temuannya bahwa penggunaan model pembelajaran induktif-deduktif dapat meningkatkan hasil belajar servis bolavoli siswa Surakarta. Persoalan di atas diteliti pada siswa kelas $\mathrm{X}$ artinya belum banyak penelitian serupa yang dilakukan pada siswa SD kelas awal dengan focus pada kreatifitas gerak melalui strategi pembelajaran yang sesuai.

Gerak merupakan ekspresi murni seoarang anak dapat dilakukan secara spontan, kapan saja dan diman saja dengan mengunakan anggota tubuhnya. Gerak merupakan kebutuhan dasar siswa SD, pentingnya gerak yang menstimulasi atau penghubung perkembang belahan otak kanan dan kiri. Demikian pentinnya keterampilan gerak secara kreatif sebagai wahana pengembang aspek lain sepeti bahasa, kognitif dan social emosional siswa SD.

Tujuan kedua adalah agar siswa dapat mengetahui bagaimana pengetahuan dibangun sehingga siswa mengerti asal usul pengetahuan yang didapatnya tidak hanya menghafalkan fakta-fakta.
Seperti yang dikemukakan oleh Cruikshank, Jenkins, dan Metcalf (2006) bahwa karakteristik strategi pembelajaran induktif adalah: (1) Peran guru bukan sebagai pemberi pengetahuan, tetapi lebih kepada menciptakan dan membimbing pembelajaran di kelas, dimana siswa terlibat untuk melakukan kegiatan-kegiatan induktif, (2) Karena siswa terlibat aktif dalam kegiatan-kegiatan induktif, guru memicu siswa untuk berfikir lebih kritis, Guru membantu siswa untuk berfikir melalui gagasan-gagasan siswa sendiri dan membantu siswa untuk memfomulasikan pengalamanpengalaman yang bermakna: Siswa menerima tantangan untuk menemukan sesuatu secara mandiri, tidak diberi tahu jawaban secara langsung oleh guru. Proses pembelajaran dengan strategi induktif ditandai oleh tingginya partisipasi dan interaksi siswa. Banyak ide-ide yang dilontarkan dan diterima oleh siswa. Selanjutnya dipertegas oleh. Ahern, dkk (2011: 68-71) bahawa kegiatan gerak secara induktif atau melalui pendekatan 
bermain dapat meningkatakan kreatifitas anak SD.

Menurut Jaromilek dan Foster (1988) dengagn pendekatan deduktif guru menjadi sumber informasi yang penting sekaligus komponen penting dalam proses pembelajaran PJOK. Guru mengatur program belajar dan guru juga yang menentukan gerak yang harus dilakukan sesuai dengan materi pelajaran yang akan dikuasai siswa. Di samping itu, guru juga berperan dalam membimbing siswa untuk memperoleh keterampilan gerak yang benar sebagaimana yang dituntut dalam kurikulum. Pengarahan dan penjelasan guru dalam strategi pembelajaran deduktif harus jelas sehingga bisa dipahami dan dikuasai siswa. Pertanyaan dan penjelasan yang kurang jelas dapat membingungkan dan menghambat belajar siswa. Melalui strategi induktif mendorong siswa SD menjadi lebih percaya diri karena dikondisikan mereka melakukan kesalahan dan belajar dari kesalahannya. Strategi induktif menyiapkan kegiatan yang kaya, bermakna serta memunculkan karakter siswa berfikir flesibel, keberanian mengambil resiko.

\section{Pengalaman Gerak}

Pengalaman gerak siswa adalah jumlah waktu siswa dalam beraktivitas gerak yang dialamani sepanjang hari atau waktu tertentu. Pengalaman gerak yang diidentikan dengan kesempatan anak dalam memperoleh kegiatan aktivitas fisik motorik kasar baik di luar (indoor) maupun di luar (outdoor).

Aktivitas fisik dapat berupa berdiri, berjalan, berlari, melompat, menarik, melempar, menangkap yang dilaksanakan pada kegoiatan bermain, berolahraga baik secara formal maupun informal, baik dilasanakan di berbagai lingkungan sepert bermain bergerak dilingkungan rumah, sekolah atau tempat-tempar rekrerasi lainnya.

\section{METODE PENELITIAN}

Penelitian menggunakan metode eksperimen dengan desain treatmen by level 2 X 2. Pemilihan metode ini berdasarkan prinsip penelitian eksperimen yaitu adanya perlakuan (treatment). Variabel terikat adalah kreativitas gerak, 
sedangkan perlakuan (treatment) strategi pembelajaran induktif dan strategi pembelajaran deduktif. Variabel aktif adalah strategi pembelajaran induktif $\left(\mathrm{A}_{1}\right)$ dan strategi pembelajaran deduktif $\left(\mathrm{A}_{2}\right)$. Sedangkan variabel atributnya adalah pengalaman gerak yaitu siswa yang memiliki pengalaman gerak kelompok tinggi $\left(\mathrm{B}_{1}\right)$ dan siswa yang memiliki pengalaman gerak kelompok rendah $\left(\mathrm{B}_{2}\right)$. Tujuan penelitian ini adalah

1. Perbedaan kreativitas gerak antara siswa yang mendapat strategi pembelajaran induktif dengan siswa yang mendapat strategi pembelajaran deduktif.

2. Interaksi antara strategi pembelajaran dan pengalaman gerak terhadap kreativitas gerak.

3. Perbedaan kreativitas gerak siswa yang memiliki pengalaman gerak tinggi, antara siswa yang mendapat strategi pembelajaran induktif dengan siswa yang mendapat strategi pembelajaran deduktif.

4. Perbedaan kreativitas gerak siswa yang memiliki pengalaman gerak rendah, antara

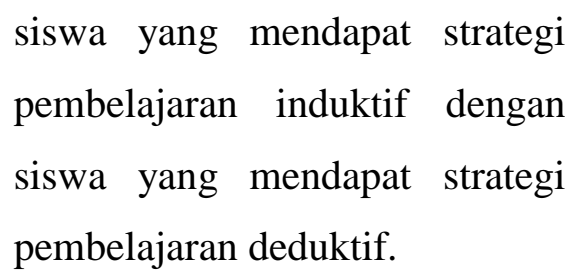

Penelitian ini dilaksanakan di SDN Karawaci 07 Kota Tangerang Banten. Waktu penelitian berlangsung selama 4 bulan dari bulan Februari sampai dengan bulan Mei tahun 2016.

Populasi penelitian seluruh kelas III Kecamatan Karawaci Kabupaten Tangerang. Pengambilan sampel dengan teknik simple random samplingyaitu pengambilan sampelnya berdasarkan daerah populasi yang telah ditetapkan. Teknik sampling ini digunakan melalui dua tahap, yaitu tahap pertama menentukan daerah sampel dan tahap berikutnya menentukan responden pada daerah itu secara sampling. Pertama mengundi satu dari 3 gugus di Kecamatan Karawaci yang akan dijadikan sampel dan selanjutnya mengundi kelas dari gugus terpilih untuk dijadikan sampel yang sesuai dengan kriteria dalam penelitian. 
Dalam gugus terpilih dari satu SDN yang sesuai dengan kriteria dalam penelitian. Kemudian menentukan kelas yang akan dijadikan sebagai kelas eksperimen secara acak melalui undian dan terpilih Kelas III B berjumlah 48 siswa, Selanjutnya Sekolah tersebut dijadikan sebagai sampel, satu kelas diberi perlakuan menggunakan strategi induktif dan satu kelas yang lainnya diberi perlakuan menggunakan strategi deduktif.

Menetapkan kelompok anak yang memliki penalaman gerak tinggi dan kelompok anak yang memiliki pengalaman gerak rendah. Semua anak yang telah terpilih secara random pada langkah 1 , diobservasi melalui angket tentang informasi pengalaman gerak siswa pada kelompok yang mempunyai tingkat pengalaman gerak dilakukan dengan menyusun urutan responden berdasarkan skor yang diperolehnya, yaitu dari skor tertinggi hingga skor terendah. Untuk mendapatkan kelompok tinggi dan kelompok rendah, ukuran dengan menentukan kelompok tinggi dan kelompok rendah adalah $27 \%\left(\mathrm{M}_{\mathrm{T}}=\mathrm{M}_{\mathrm{R}}=\right.$ 27\%) dimana angka ini cukup kontras dan reliabel.

\section{HASIL DAN PEMBAHASAN}

Hasil penelitian dapat dideskripsi data yang berhubungan dengan variabel-variabel yang diteliti yaitu: variabel terikat kreativitas gerak, variabel bebas yang terdiri dari strategi pembelajaran dan pengalaman gerak.

Tabel 1

Deskripsi sebaran data secara keseluruhan

\begin{tabular}{lccccccc}
\hline \multicolumn{1}{c}{ Sebaran statistika } & A1 & A2 & A1B1 & A2B1 & \multicolumn{1}{c}{ A1B2 } & \multicolumn{1}{c}{ A2B2 } \\
\hline \multicolumn{1}{c}{$(\mathbf{1})$} & $\mathbf{( 2 )}$ & $\mathbf{( 3 )}$ & $\mathbf{( 4 )}$ & $\mathbf{( 5 )}$ & \multicolumn{1}{c}{$(\mathbf{6})$} & \multicolumn{1}{c}{$\mathbf{( 7 )}$} \\
\hline $\mathrm{n}$ & 24 & 24 & 12 & 12 & 12 & 12 \\
\hline Mean & 31.3333 & 26.8333 & $\mathbf{3 4 . 2 5 0 0}$ & $\mathbf{2 7 . 1 6 6 7}$ & 28.4167 & 26.5000 \\
\hline Median & 31.5000 & 27.0000 & 34.5000 & 27.5000 & 28.0000 & 27.0000 \\
\hline Mode & $28.00^{\mathrm{a}}$ & $27.00^{\mathrm{a}}$ & $34.00^{\mathrm{a}}$ & $24.00^{\mathrm{a}}$ & 28.00 & 27.00 \\
\hline Std. Deviation & 4.16681 & 2.44357 & 3.27872 & 3.24271 & 2.64432 & 1.31426 \\
\hline \multicolumn{1}{c}{$\mathbf{( 1 )}$} & $\mathbf{( 2 )}$ & $\mathbf{( 3 )}$ & $\mathbf{( 4 )}$ & $\mathbf{( 5 )}$ & $\mathbf{( 6 )}$ & $\mathbf{( 7 )}$ \\
\hline Variance & 17.362 & 5.971 & 10.750 & 10.515 & 6.992 & 1.727 \\
\hline
\end{tabular}




\begin{tabular}{lrrrrrr}
\hline Skewness & .061 & .074 & -.749 & -.198 & -.153 & -.577 \\
\hline Std. Error of Skewness & .472 & .472 & .637 & .637 & .637 & .637 \\
\hline Kurtosis & -.850 & 1.085 & .980 & -.091 & -.998 & -.613 \\
\hline Std. Error of Kurtosis & .918 & .918 & 1.232 & 1.232 & 1.232 & 1.232 \\
\hline Range & 15.00 & 11.00 & 12.00 & 11.00 & 8.00 & 4.00 \\
\hline Minimum & 24.00 & 21.00 & 27.00 & 21.00 & 24.00 & 24.00 \\
\hline Maximum & 39.00 & 32.00 & 39.00 & 32.00 & 32.00 & 28.00 \\
\hline Sum & 752.00 & 644.00 & 411.00 & 326.00 & 341.00 & 318.00 \\
\hline
\end{tabular}

a. Multiple modes exist. The smallest value is shown

(Sumber: Perhitungan dengan program SPSS 17)

Hipotesis dalam penelitian ini secara inferensia diuji dengan menggunakan Analisis Varians (ANOVA) dua jalan. Dalam penelitian ini terdapat dua variabel bebas dan satu variabel kriteria.

\begin{abstract}
Variabel bebas adalah (1) Strategi Pembelajaran (induktif dan deduktif) dan (2) pengalaman gerak (tinggi dan rendah). Sedangkan variabel kriteria adalah kreativitas gerak.
\end{abstract}

Tabel 2

Ringkasan Analisis Varians Dua jalan

\begin{tabular}{|c|c|c|c|c|c|c|}
\hline \multirow[b]{2}{*}{ Sumber Varians } & \multirow{2}{*}{$\mathbf{J K}$} & \multirow{2}{*}{ Db } & \multirow{2}{*}{ RJK } & \multirow{2}{*}{ Fo } & \multicolumn{2}{|c|}{ F-tabel } \\
\hline & & & & & 0,05 & $\mathbf{0 , 0 1}$ \\
\hline Antar A & 243,00 & 1 & 243,00 & 32,42 & 3,95 & 7,19 \\
\hline Antar B & 126,75 & 1 & 126,75 & 16,91 & & \\
\hline Interaksi AB & 80,08 & 1 & 80,08 & 10,68 & & \\
\hline Antar Kelompok & 449,83 & 3 & 149,94 & 20,00 & 2,7 & 3,98 \\
\hline Dalam (D) & 329,83 & 44 & 7,50 & & & \\
\hline Total $(\mathrm{T})$ & 779,67 & 47 & & & & \\
\hline
\end{tabular}

Dari hasil perhitungan Analisis Varians (ANOVA) di atas dapat dijelaskan beberapa hal sebagai berikut :

1. Perbedaan kreativitas gerak siswa yang diberi strategi Pembelajaran induktif (A1) dengan siswa yang diberi

\section{strategi pembelajaran deduktif}

(A2)

Hasil analisa data dengan menggunakan ANOVA dua jalur pada taraf signifikansi $\alpha=0,05$, tersebut di atas, memberikan nilai $F_{\text {hitung }}\left(F_{0}\right)=32,42$ lebih besar dari 
$F_{\text {tabel }}\left(F_{t}\right)=3$,95. Hal ini berarti bahwa $\mathrm{H}_{\mathrm{o}}$ ditolak. Sebagai konsekuensinya maka $\mathrm{H}_{1}$ diterima. Nilai rata-rata kreativitas siswa yang diberi strategi pembelajaran induktif sama dengan 31,33 lebih tinggi dari pada nilai rata-rata kreativitas siswa yang diberi strategi pembelajaran deduktif sama dengan 26,83. Dengan demikian dapat disimpulkan bahwa kreativitas siswa yang diberi strategi pembelajaran induktif lebih tinggi dari kreativitas siswa yang diberi strategi pembelajaran deduktif, dengan kata lain bahwa kelompok $\mathrm{A}_{1}>$ kelompok $\mathrm{A}_{2}$.

\section{Interaksi antara strategi pembelajaran dengan pengalaman gerak terhadap kreativitas}

Hasil analisa data dengan menggunakan ANOVA dua jalur pada taraf signifikansi $\alpha=0,05$, tersebut di atas, memberikan nilai $F_{\text {hitung }}\left(F_{0}\right)=10,68$ lebih besar dari $F_{\text {tabel }}\left(F_{t}\right)=3,95$. Hal ini berarti bahwa $\mathrm{H}_{\mathrm{o}}$ ditolak. Sebagai konsekuensinya maka $\mathrm{H}_{1}$ diterima. Dengan demikian dapat disimpulkan bahwa terdapat interaksi yang signifikan antara strategi pembelajaran dengan pengalaman gerakterhadap kreativitas gerak siswa.

Untuk memperjelas terjadinya interaksi tersebut, berikut ini akan disajikan grafik yang menunjukan interaksi yang dimaksud sebagai berikut :

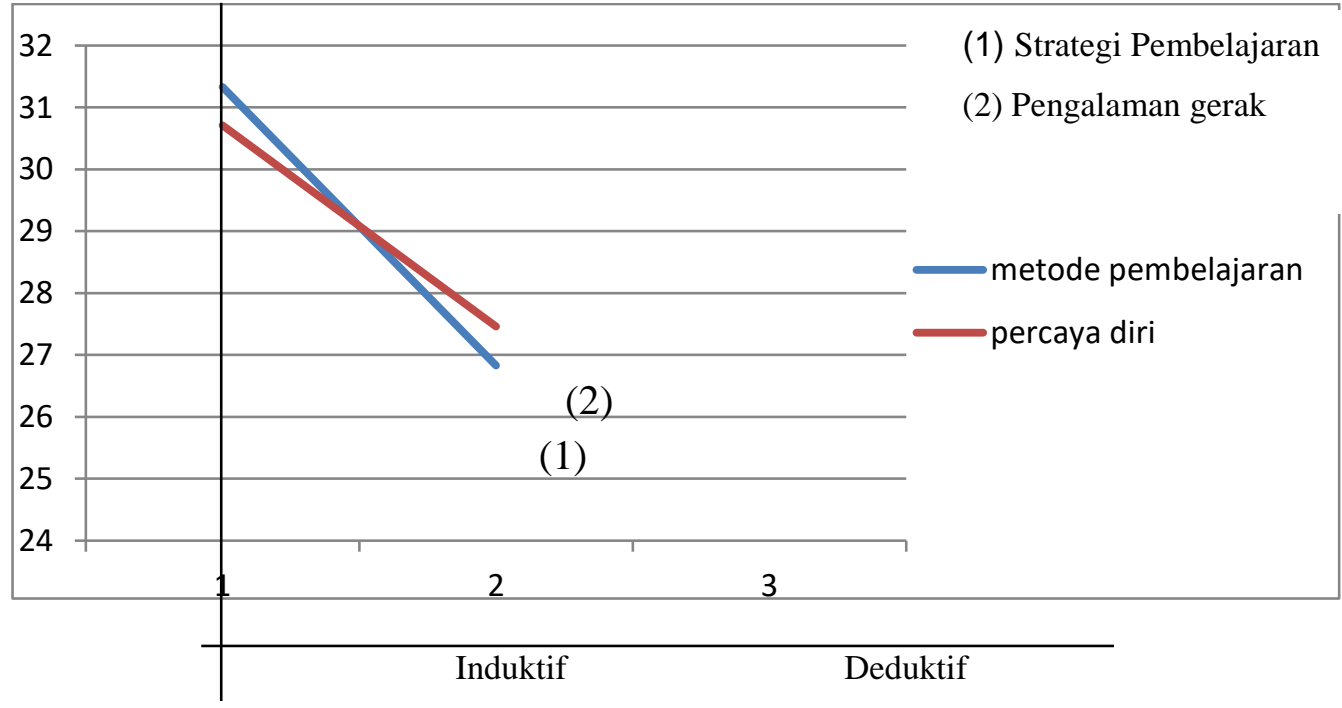

Gambar 1

Grafik interaksi strategi pembelajaran dengan pengalaman gerak 
Dari grafik tersebut di atas terlihat ada empat titik yang dihubungkan oleh dua garis yang berpotongan. Keempat titik tersebut merupakan nilai rata-rata dari masing-masing kelompok, yaitu secara singkat dapat disebutkan sebagai kelompok strategi pembelajaran induktif, kelompok strategi pembelajaran deduktif, kelompok pengalaman gerak tinggi, dan kelompok pengalaman gerak rendah. Dua garis yang berpotongan menunjukan bahwa terjadi interaksi antara kedua variable bebas yaitu strategi pembelajaran dengan pengalaman gerakterhadap variable teikat, yaitu kreativitas gerak siswa. Interaksi tersebut merupakan kerjasama antara strategi pembelajaran dengan pengalaman gerak. Interaksi dalam hal ini juga dapat diartikan sebagai pengaruh strategi pembelajaran terhadap kreativitas yang bergantung pada pengalaman gerakatau sebaliknya.

$$
\text { Dengan adanya pengaruh }
$$
interaksi yang sangat signifikan antara strategi pembelajaran dengan pengalaman gerak, maka dilakukan uji perbandingan ganda (multiple comparation). Pengujian ini dimaksudkan untuk mengetahui rerata skor group mana yang berbeda secara signifikan. Karena jumlah sampel setiap sel (group) sama maka digunakan uji Tukey.Uji Tukey dilakukan terhadap rerata skor group $\mathrm{A}_{1} \mathrm{~B}_{1}$ dengan $\mathrm{A}_{1} \mathrm{~B}_{2}$, dan $\mathrm{A}_{2} \mathrm{~B}_{1}$ dengan $\mathrm{A}_{2} \mathrm{~B}_{2}$. Hasil pengujian tersebut pada taraf signifikansi $\alpha=0,05$ dirangkum pada tabel 4 berikut:

Tabel 3

Rangkuman Hasil Perhitungan Uji Signifikansi Perbedaan Rerata Kreativitas Gerak Siswa DenganUji Tukey

\begin{tabular}{ccccc}
\hline \multirow{2}{*}{ Pasangan Kelompok } & \multirow{2}{*}{ Q hitung } & \multicolumn{2}{c}{ Q tabel } \\
\cline { 5 - 5 } & & & $\mathbf{0 , 0 5}$ & $\mathbf{0 , 0 1}$ \\
\hline $\mathrm{A}_{1} \mathrm{~B}_{1}$ dengan $\mathrm{A}_{2} \mathrm{~B}_{1}$ & 8,96 & & 4,26 & 5,62 \\
\hline $\mathrm{A}_{1} \mathrm{~B}_{2}$ dengan $\mathrm{A}_{2} \mathrm{~B}_{2}$ & 2,43 & & \\
\hline
\end{tabular}

Dari hasil uji Tukey di atas, dapat dijelaskan: 
1. Perbedaan kreativitas siswa yang diberi strategi pembelajaran induktif dengan siswa yang diberi strategi pembelajaran deduktif pada kelompok siswa yang memiliki pengalaman gerak tinggi

Dengan uji-Tukey untuk kelompok $\mathrm{A}_{1} \mathrm{~B}_{1}$ dengan $\mathrm{A}_{1} \mathrm{~B}_{2}$, didapatkan harga $Q_{\text {hitung }}=8,96$ dan $Q_{\text {tabel }}$ dengan $\alpha=0,05, \mathrm{dk}=\mathrm{n}-1=12$ $1=11$ adalah 4,26. Dengan demikian, $Q_{\text {hitung }}=8,96$ lebih besar daripada $Q$ tabel $=4,26$. Hasil analisa data dengan menggunakan uji Tukey antara siswa yang diberi strategi pembelajaran induktif dengan hasil belajar siswa yang diberi strategi pembelajaran deduktif pada kelompok siswa yang memiliki pengalaman gerak tinggipada taraf signifikansi $\alpha=$ 0,05 , tersebut di atas, $Q_{\text {hitung }}=8,96$ lebih besar daripada $Q_{\text {tabel }}=4,26$. Hal ini berarti bahwa $\mathrm{H}_{0}$ ditolak. Sebagai konsekuensinya maka $\mathrm{H}_{1}$ diterima. Dilihat dari rata-rata (tabel 2) menunjukan bahwa kreativitas siswa yang diberi strategi pembelajaran induktif yang memiliki pengalaman gerak tinggiyaitu $=34,25$ lebih tinggi dari kreativitas gerak siswa yang diberi strategi pembelajaran deduktif yang memiliki pengalaman gerak tinggi yaitu = 27,17, dengan kata lain bahwa kelompok $\mathrm{A}_{1} \mathrm{~B}_{1}>$ kelompok $\mathrm{A}_{2} \mathrm{~B}_{1}$.

2. Perbedaan kreativitas gerak siswa yang diberi strategi pembelajaran induktif dengan siswa yang diberi strategi pembelajaran deduktif pada kelompok siswa yang memiliki pengalaman gerak rendah

Dengan uji-Tukey untuk kelompok $\mathrm{A}_{1} \mathrm{~B}_{1}$ dengan $\mathrm{A}_{1} \mathrm{~B}_{2}$ didapatkan, harga $Q_{\text {hitung }}=2,43$ dan harga $Q_{\text {tabel }}$ dengan $\alpha=0,05 \mathrm{dk}=\mathrm{n}$ 1=12-1=11 adalah 4,26. Dengan demikian, $Q_{\text {hitung }}=2,43$ lebih kecil daripada $Q_{\text {tabel }}=4,26$. Hasil analisa data dengan menggunakan uji Tukey antara siswa yang diberi strategi pembelajaran induktif dengan hasil belajar siswa yang diberi strategi pembelajaran deduktif pada kelompok siswa yang memiliki pengalaman gerak rendah pada taraf signifikansi $\alpha=0,05$, tersebut di atas, $Q_{\text {hitung }}=2,43$ lebih kecil daripada $Q$ tabel $=4,26$. Hal ini berarti bahwa $\mathrm{H}_{0}$ diterima. Sebagai konsekuensinya maka $\mathrm{H}_{1}$ ditolak. Dilihat dari rata-rata menunjukan bahwa kreativitas gerak siswa yang diberi strategi 
pembelajaran induktif yang memiliki pengalaman gerak rendah yaitu $=28,42$ lebih tinggi dari kreativitas gerak siswa yang diberi strategi pembelajaran deduktif yang memiliki pengalaman gerak rendah yaitu $=26,50$, dengan kata lain bahwa kelompok $\mathrm{A}_{1} \mathrm{~B}_{2}<$ kelompok $\mathrm{A}_{2} \mathrm{~B}_{2}$ tidak terdapat perbedaan yang signifikan, atau dengan kedua cara ini memberikan hasil yang relatif sama.

\section{Dari pengujian hipotesis} pertama, diperoleh bahwa terdapat perbedaan antara kreativitas gerak siswa yang diberikan strategi pembelajaran induktif dengan kreativitas gerak siswa yang diberikan strategi pembelajaran deduktif. Hasil ini menunjukan bahwa kreativitas gerak siswa yang diberi strategi pembelajaran induktif lebih tinggi dari kreativitas siswa yang diberikan strategi pembelajaran deduktif. Seperti didukung oleh temuan penelitian Theodoraki dkk (2007: 247) kretivitas gerak dikembangkan oleh aktifitas yang beragam melalui kegiatan improvisasi induktif.
Hasil penelitian oleh Oppezzo dan Schwartz (2014: 1142) menyimpulkan bahwa stimulasi kegiatan bervariasi di luar kelas memberikan pengaruh signifikan terhadap kreativitas dan kebugaran jasmani anak.

Temuan penelitian Ahern dkk (2012: 68-71) menunjukan strategi pembelajaran induktif pada siswa SD kelas awal telah mengembangkan potensi kreatif gerak, strategi induktif mendorong siswa SD mampu bereksplorasi, berimajinasi, bergerak, suasana menyenangkan siswa terstimulan dalam menemukan aneka gerak berbeda dan bervariasi seperti mampu mengkombinasikan gerak jalan, lari dan lompat serta lempar dengan pola gerak yang berbeda beda, seperti arah, kecepatan, kekuatan dan bentuk gerak. Břehovský dkk (2011: 43) menegaskan sebagai berikut:

A natural question arises whether the increase in the proportion of those methods would help improvement of the process of teaching and learning. in accordance with above mentioned results one can assume that greater representation of inductive and deductive methods would 
affect the quality of teaching and at the same time, helped to increase the use of these methods by teachers themselves.

Sedangkan strategi pembelajaran deduktif cendrung menekankan penyampaian instruksi gerak yang bersumber dari guru dengan cara komando dengan urutan : “dengar, lihat dan lakukan”.Hal yang berbeda dengan strategi pembelajaran induktif, siswa tidak hanya menerima informasi dari guru, melainkan siswa menerima respons dan mencoba beraktivitas gerak secara bebas atau menerapkan suatu generalisasi untuk memperoleh perbendaharaan gerak (vocabulary movement) tertentu.

Hasil penelitian Vogel, dkk (2011: 370) mendukung penjelasan di atas walau dalam ranah bahasa bahwa strategi induktif berpengaruh positif terhadap perolehan perbendaharaan bahasa dari pada strategi deduktif yang kurang mendukung kreativitas siswa.

Oleh karena itu, walaupun kedua strategi pembelajaran ini memiliki kemampuan membentuk keunggulan yang lebih baik terhadap kreativitas gerak/perbendaharaan gerak siswa, tetapi strategi pembelajaran induktif tetap akan dapat memberikan hasil yang lebih baik dari pada strategi pembelajaran deduktif.

Berdasarkan temuan yang diperoleh dari hasil penelitian ini, dapat disimpulkan bahwa kreativitas siswa yang diberi strategi pembelajaran induktif lebih tinggi dari kreativitas siswa yang diberi strategi pembelajaran deduktif .

Dari pengujian hipotesis kedua, diperoleh bahwa terdapat perbedaan antara kreativitas siswa yang diberi strategi pembelajaran induktif yang memiliki pengalaman gerak tinggi dengan kreativitas gerak siswa yang diberi strategi pembelajaran deduktif. Hasil ini menunjukan bahwa kreativitas gerak siswa yang diberi strategi pembelajaran induktif yang memiliki pengalaman gerak tinggi lebih tinggi dari kreativitas gerak siswa yang diberi strategi pembelajaran deduktif yang memiliki pengalaman gerak tinggi.

Berdasarkan perbedaan ini dapat dijelaskan Bycroft, M. (2012: 
197-214) bahwa pada proses pembelajaran dengan strategi pembelajaran induktif siswa tidak hanya menerima tugas gerak dari guru, melainkan juga dapat memberikan respons melalui jawaban atau menerapkan tugas tugas gerak tertentu. Tidak dapat dipisahkan bahwa kreativitas sangat terkait dengan peran kognitif dan berfikir kritis yang diterapkan dalam domain gerak. Hal ini didukung oleh hasil penelitian Chennault(2010: 161) pendekatan induktif mendorong siswa mampu berfikir memahami konsep secara mendalam melalui proses konstruksi pengetahuan yang dimilikinya melalui media gerak. Temuan penelitian ini juga menunjukan bahwa pembelajaran PJOK dikelas awal SD tidak hanya melibatkan aktifitas fisik jasmani saja tetapi terintegrasi dengan ketrampilan berfikir siswa.

Sedangkan strategi deduktif adalah cara penyampaian tugas gerak yang bersifat statis. Hal ini sejalan dengan siswa yang memiliki pengalaman gerak yang tinggi dapat menyelesaikan tugas gerak dengan baik atau setidaknya memiliki kemampuan untuk belajar cara menyelesaikan tugas gerak tersebut tanpa tergantung dengan orang lain dan mempunyai keberanian untuk meningkatkan prestasinya sendiri. Penelitian menunjukan bahwa salah satu unsur kreativitas gerak adalah pengalaman gerak. Menurut Brusic, Sharon A (2014: 11-15)kreativitas mempunyai kaitan erat dengan pengalaman terdahulu, karena tanpa adanya pengetahuan awal seseorang tidak dapat mempunyai kesiapan untuk melakukan tugas gerak yang berbeda, siswa memiliki pengalaman gerak tinggi tidak akan terjebak pada kekhawatiran dan ketakutan untuk bergerak dengan cara lain.

Berdasarkan temuan yang diperoleh dari hasil penelitian ini, bahwa kreativitas gerak siswa yang diberi strategi pembelajaran induktif yang memiliki pengalaman gerak tinggi lebih tinggi dari kreativitas gerak siswa yang diberi pembelajaran deduktif yang memiliki pengalaman gerak tinggi.

Dari pengujian hipotesis ketiga, bahwa tidak terdapat perbedaan kreativitas gerak siswa yang diberi 
strategi pembelajaran induktif dengan siswa yang diberi strategi pembelajaran deduktif pada kelompok siswa yang memiliki pengalaman gerak rendah.

Hasil ini menunjukan bahwa kreativitas gerak siswa yang diberi strategi pembelajaran induktif yang memiliki pengalaman gerak rendah reatif sama dari kreativitas siswa yang diberi strategi pembelajaran deduktif yang memiliki pengalaman gerak rendah. Hal ini dapat dilihat pada uji perbedaan pada dua kelompok tersebut. Dengan kata lain bahwa kedua kelompok itu tidak terdapat perbedaan yang signifikan, atau dengan kedua cara ini memberikan hasil yang relatif sama.Berdasarkan perbedaan ini dapat dijelaskan bahwa strategi pembelajaran deduktif betapapun tidak mungkin ditinggalkan dalam proses pembelajaran gerak.

Strategi pembelajaran deduktif memberikan dua keuntungan utama yaitu dari segi waktu dan pengawasan. Melalui strategi pembelajaran deduktif materi tugas gerak dapat cepat disampaikan dan dikuasai siswa. Lebih dari itu strategi ini relatif diperlukan dalam pembelajaran yang diikuti oleh jumlah siswa yang terlalu besar.

Oleh karena itu, walaupun kedua strategi pembelajaran ini memiliki kemampuan membentuk keunggulan yang lebih baik terhadap kreativitas siswa, tetapi pada kelompok siswa yang memiliki pengalaman gerak rendah menunjukan bahwa strategi pembelajaran induktif memberikan hasil yang relatif sama pada strategi pembelajaran deduktif (Çocukluk, 2011:594) .

Berdasarkan temuan yang diperoleh dari hasil penelitian ini, bahwa kreativitas gerak siswa yang diberi strategi pembelajaran induktif yang memiliki pengalaman gerak rendah, rendah relatif sama dengan kreativitas siswa yang diberi strategi pembelajaran deduktif yang memiliki pengalaman gerak rendah.

Dari pengujian hipotesis kedua, diperoleh hasil penelitian bahwa terdapat pengaruh interaksi antara strategi pembelajaran dengan pengalaman gerak terhadap kreativitas gerak siswa menunjukan adanya pengaruh yang signifikasi. 
Hal ini mengindikasikan bahwa, ketepatan suatu strategi pembelajaran pada mata pelajaran PJOK di kelas awal SD berhubungan erat dengan pengalaman gerak siswa pada temuan ini memberikan makna bahwa, pengalaman gerak siswa memberikan efek terhadap perlakuan eksperimental yakni strategi pembelajaran melalui strategi pembelajaran induktif dan strategi pembelajaran deduktif, yang efek tersebut selanjutnya berpengaruh terhadap kreativitas gerak siswa. Selain itu, temuan penting penelitian ini adalah menjelaskan pula bahwa ketepatan strategi pembelajaran behubungan erat dengan latarbelakang dan karakteristik siswa yang mengikuti proses belajar mengajar yang sekaligus menjadi subjek penelitian.

\section{KESIMPULAN}

Penelitian ini telah dilakukan pada siswa kelas III Sekolah Dasar dan temuan dari penelitian tersebut dapat disimpulkan sebagai berikut: (1) secara keseluruhan stimulasi pembelajaran induktif lebih optimal dalam mencapai kreativitas gerak siswa kelas awal dari pada strategi pembelajaran deduktif.

kreativitas gerak siswa yang memiliki pengalaman gerak tinggi akan optimal jika diberikan strategi pembelajaran induktif. (3) sebaliknya strategi pembelajaran deduktif kurang optimal dalam pencapaian kreativitas gerak siswa yang memiliki pengalaman gerak tinggi. Dengan demikian maka dapat ditegaskan bahwa untuk mencapai kreativitas gerak yang optimal perlu dilakukan dengan memilih strategi pembelajaran yang tepat dan kontinu dengan memperhatikan tingkat pengalaman gerak siswa.

\section{DAFTAR PUSTAKA}

Ahern, Rose; Beach, Rebecca; Leibke, Stephanie Moats; Proud, Ian; Spencer, AnneMarie; Strickland, Eric. (2011).The Benefits of Play Go Well Beyond Physical Fitness. Periodical Exchange Journal.

Břehovský, Jiř́i; Emanovský, (2011). On usage of inductive approach in mathematical textbooks at secondary school. Petr. Problems of Education in the 21st Century. 
Brusic, Sharon A (2014). Ttransform me! promoting children'screativitythrough newfangled upcycling. Academic Journal, Children's Technology \& Engineering.

Bycroft, M. (2012). Psychology, Psychologists, and the Creativity Movement: The Lives of Method Inside and Outside the Cold War. InCold War Social Science (pp. 197214). Palgrave Macmillan US.

Cruickshank Donald R., Deborah Brainer Jenkins, and Kim K. Metcalf (2006), The ct of Teaching, Boston: Mc Graw Hill.

Chennault, Ronald E (2010). Teaching graduate students about social class: Using a classifying activity with an inductive approach. Multicultural Education.

Furqon Nur Ramdhani (2012). Penerapan pembelajaran induktif-deduktif untuk meningkatkan hasil belajar servis bawah bola voli pada siswa kelas $\mathrm{x}$ multimedia 1 sekolah menengah kejuruan negeri 6 Surakarta tahun ajaran 2011/2012. Skripsi: UNS-FKIP Jur. Pendidikan Olahraga dan Kesehatan-K.5607010-2012
Cheung, R. H. P. (2010). Designing movement activities to develop children's creativity in early childhood education. Early Child Development and Care.

Dow, Connie Bergstein (2010). Young Children and Movement: The Power of Creative Dance. YC: Young Children.

Erken Çocukluk (2011). The Development and Support of Creativity in Early Childhood Period. International Online Journal of Educational Sciences.

Effectiveness of a Guided Inductive Versus a Deductive Approach on the Learning of Grammar in the Intermediate-Level College French Classroom.Foreign Language Annals.

Jautakytè, Rasa. (2014). The concept and development of creativity ev the kindergarten: The position of pre-school pedagogues.Tiltai Jounal 2014,

Vogel, Séverine; Herron, Carol; Cole, Steven P.; York, Holly (2011). 